\title{
PENGARUH KEMAMPUAN GURU DALAM MENGELOLA KELAS TERHADAP PEMBELAJARAN EFEKTIF DI TAMAN KANAK- KANAK
}

\author{
Nopi Sri Rejeki ${ }^{1}$; Suwardi ${ }^{1}$ \\ ${ }^{1}$ Program Studi Pendidikan Guru Pendidikan Anak Usia Dini, Fakultas Psikologi dan Pendidikan, \\ Universitas Al-Azhar Indonesia, Jalan Sisingamangaraja, Kebayoran Baru, Jakarta Selatan 12110 \\ Penulis untuk Korespondensi/E-mail: suwardi@uai.ac.id
}

\begin{abstract}
Abstrak - Kemampuan guru dalam mengelola kelas yaitu menciptakan dan memelihara kondisi belajar yang menyenangkan, mempersiapkan sarana dan prasarana, mengatur ruang belajar dan mengatur waktu guna mencapai tujuan pembelajaran yang diharapkan. Penelitian ini bertujuan untuk mengkaji dan mendapatkan data secara empiris tentang pengaruh kemampuan guru dalam mengelola kelas terhadap pembelajaran efektif di Taman Kanak-Kanak Kecamatan Rangkasbitung. Penelitian ini menggunakan metode penelitian ex post facto dan sampel penelitian ini adalah 38 guru yang mengajar di Taman Kanak-Kanak Kecamatan Rangkasbitung, yang dipilih menggunakan teknik random sampling. Pengumpulan data menggunakan angket/ kuesioner tertutup dengan alat ukur skala likert. Teknik analisis data yang digunakan adalah analisis regresi sederhana menggunakan program software SPSS. Hasil penelitian menunjukan bahwa terdapat hubungan positif antara kemampuan guru dalam mengelola kelas dan pembelajaran efektif di TK dengan nilai persamaan regresi $\hat{Y}=$ $54,256+135$, dan besaran R Square sebesar 1.6\%.
\end{abstract}

Kata Kunci: Pengelolaan Kelas, Pembelajaran Efektif, Taman Kanak-Kanak

Abstract - The ability of teachers to manage classes is to create and maintain pleasant learning conditions, prepare facilities and infrastructure, organize learning spaces and arrange time to achieve the expected learning goals. This study aims to assess and obtain empirical data about the effect of the ability of teachers in managing classrooms for effective learning in kindergarten in Rangkasbitung sub-district. This study used an ex post facto research method and the sample of this study was 38 teachers who taught in kindergarten in Rangkasbitung District, who were selected using random sampling techniques. Data collection uses a closed questionnaire / questionnaire with a Likert scale measurement tool. The data analysis technique used is a simple regression analysis using the SPSS software program. The results showed that there was a positive relationship between the ability of teachers to manage classrooms and effective learning in kindergarten with a regression equation value $\hat{Y}=54.256+135$, and the amount of $R$ Square of $1.6 \%$.

Keywords: Classroom Management, Learning Efectiveness in Kindergarten

\section{PENDAHULUAN}

$P^{-}$ endidikan anak usia dini (PAUD) adalah pemberian upaya untuk menstimulasi, membimbing, mengasuh, dan memberikan kegiatan pembelajaran yang akan menghasilkan kemampuan dan keterampilan anak. Menurut Undang-Undang Nomor 20 Tahun 2003 tentang Sistem Pendidikan Nasional berkaitan dengan pendidikan anak usia dini pada bab I pasal 1 ayat 14 ditegaskan bahwa pendidikan anak usia dini adalah suatu upaya pembinaan yang ditujukan kepada anak sejak lahir sampai usia enam tahun yang dilakukan melalui pemberian rangsangan pendidikan untuk membantu pertumbuhan dan perkembangan jasmani dan rohani agar anak memiliki kesiapan dalam memasuki pendidikan lebih lanjut.

Pendidikan anak usia dini merupakan salah satu bentuk penyelenggaraan pendidikan yang 
menitikberatkan pada peletakan dasar ke arah pertumbuhan dan perkembangan fisik (koordinasi motorik halus dan kasar), kecerdasan (daya pikir, daya cipta, kecerdasan emosi, kecerdasan spiritual), kecerdasan emosional (sikap dan perilaku serta beragama), bahasa dan komunikasi, sesuai dengan keunikan dan tahap-tahap perkembangan yang dilalui oleh anak usia dini. Contohnya ketika menyelenggarakan lembaga pendidikan seperti kelompok bermain (KB), taman kanak-kanak (TK), atau lembaga PAUD yang berbasis pada kebutuhan anak. Pada dasarnya lembaga pendidikan adalah tata yang dilakukan agar seseorang memperoleh pengetahuan, keterampilan, memahami diri dan lingkungan sekitarnya. Oleh Karena itu, untuk mendapatkan hal tersebut diperlukan pembelajaran yang efektif agar dapat memperoleh tujuan yang ingin dicapai.

\section{Pembelajaran Efektif di Taman Kanak- Kanak}

Menurut Sutikno (2007: 50) pembelajaran efektif adalah suatu pembelajaran yang memungkinkan siswa untuk dapat belajar dengan mudah, menyenangkan, dan dapat tercapai tujuan pembelajaran sesuai dengan yang diharapkan. Sedangkan menurut Miarso (2004: 34) pembelajaran efektif adalah pembelajaran yang menghasilkan belajar yang bermanfaat dan bertujuan bagi peserta didik, melalui pemakaian prosedur yang tepat. Hal ini sejalan dengan Syafaruddin dan Irwan (2005: 16) bahwa pembelajaran efektif adalah mengajar sesuai prinsip, prosedur, dan desain sehingga tercapai tujuan perubahan tingkah laku anak. Ketiga hal tersebut merupakan sistem pembelajaran yang harus dilakukan dalam kegiatan proses pembelajaran.

\section{a. Prinsip-prinsip pembelajaran di Taman Kanak-Kanak}

Menurut Aqip (2009: 10) Pembelajaran di TK sepatutnya memenuhi prinsip-prinsip sebagai berikut:

1) Bermain sambil belajar dan belajar sambil bermain

2) Pembelajaran disesuaikan dengan perkembangan anak

3) Pembelajaran berorientasi pada kebutuhan anak,

4) Pembelajaran di TK hendaknya menempatkan anak sebagai subjek pembelajaran,
5) Pembelajaran menggunakan pendekatan tematik,

6) Kegiatan pembelajaran yang PAKEM (pembelajaran Aktif, Kreatif, Efektif dan Menyenangkan),

7) Pembelajaran mengembangkan kecakapan hidup,

8) Pembelajaran didukung oleh lingkungan yang kondusif,

9) Pembelajaran yang demokratis,

10) Pembelajaran bermakna, pembelajaran dikaitkan dengan pengetahuan yang dimiliki anak. Dalam kegiatan pembelajaran akan terjadi interaksi yang bermakna yang dilakukan anak dengan guru, anak dengan anak yang lain serta anak dengan lingkungannya.

Dengan demikian untuk melaksanakan proses pembelajaran pada Taman Kanak-Kanak guru perlu mengetahui prinsip pembelajaran yang telah ditentukan di PAUD agar pembelajaran dapat berjalan lebih efektif dan mencapai tujuan yang diharapkan karena pembelajaran di Taman Kanak-Kanak berbeda dengan pembelajaran orang dewasa pada umumnya. Pembelajaran di Taman Kanak-Kanak memiliki ciri khas tersendiri di dalamnya.

\section{b. Prosedur Pembelajaran di Taman Kanak-Kanak}

Prinsip pembelajaran merupakan bagian yang penting yang perlu diketahui oleh seorang pengajar. Dengan mengetahui prinsip-prinsip pembelajaran guru dapat membuat suatu acuan dalam pembelajaran. Pembelajaran bagi anak usia dini hendaknya memperhatikan prinsipprinsip yang sesuai dengan kebutuhan anak seperti kegiatan bermain dan bukanlah pembelajaran selayaknya bagi orang dewasa.

Mulyasa (2013: 115) mengatakan prosedur pembelajaran di Taman Kanak-Kanak pada umumnya terdapat pada:

1) Prosedur Pengelolaan kelas

Prosedur pengelolaan kelas meliputi penataan ruangan maupun pengorganisasian peserta didik sesuai dengan kebutuhan dan program yang direncanakan akan membantu pencapaian standar kompetensi dan kompetensi dasar serta tujuan pembelajaran yang optimal (Mulyasa, 2013: 115).

2) Prosedur Kegiatan 
Menurut Mulyasa (2013: 115) pembelajaran anak usia dini dapat dilakukan dengan langkah-langkah sebagai berikut:

a) Sebelum masuk kelas, anak-anak disambut oleh guru dengan ramah dan penuh kasih sayang, mereka saling berjabat tangan dengan guru, teman sambil mengucapkan salam lalu menyimpan tas.

b) Pendahuluan, kegiatan awal dalam pembelajaran yang ditujukan untuk memfokuskan perhatian, membangkitkan motivasi, menyiapkan mental anak sehingga anak siap untuk mengikuti pembelajaran.

c) Kegiatan inti, dilakukan dengan kegiatan explorasi, ekperimen, elaborasi, dan konfirmasi.

d) Makan dan Istirahat, kegiatan ini kadang digunakan untuk mengisi indikator standar kompetensi dan kompetensi dasar yang hendak dicapai berkaitan dengan kegiatan makan, misalnya disiplin, tata tertib makan, jenis makanan bergizi, rasa sosial dan kerjasama.

e) Kegiatan Penutup, dilakukan untuk menenangkan siswa dan dibiarkan secara klasikal, misalnya mendengarkan cerita, menyanyi, dan melakukan apersepsi musik. Kegiatan ini dapat diakhiri dengan salam (Mulyasa, 2013: 116).

3) Prosedur Penilaian

Penilaian pendidikan anak usia dini dapat dilakukan dengan prosedur sebagai (Mulyasa, 2013: 120) berikut:

a) Merumuskan kegiatan

b) Menyiapkan alat penilaian

c) Menetapkan kriteria penilaian

Oleh karena itu, untuk melaksanakan proses pembelajaran, selain guru harus mengetahui prinsip-prinsip pembelajaran di TK, guru juga harus mengetahui prosedur pembelajaran di TK. Dengan mengetahui prosedur pembelajaran, guru dapat menjalankan proses pembelajaran secara berurutan dan terencana yang disesuaikan dengan model pembelajaran yang akan digunakan, sehingga proses pembelajaran dari awal sampai akhir akan berjalan lebih efektif jika guru menggunakan prosedur tersebut.

\section{c. Desain Pembelajaran di Taman Kanak- Kanak}

Menurut Seels \& Richey (dalam Yaumi, 2013: 5) desain adalah proses untuk menentukan kondisi belajar. Sebagai pendidik di Taman Kanak-Kanak guru wajib mendesain pembelajaran khusunya rencana kegiatan harian (RKH) sebelum melakukan proses pembelajaran, karena nantinya pada saat proses pembelajaran berlangsung anak tidak hanya berinteraksi dengan guru, melainkan dengan seluruh sumber yang ada, dengan begitu guru harus memberikan rancangan kegiatan yang maksimal, agar tujuan pembelajaran yang akan disampaikan kepada peserta didik dapat sampai dengan efektif. Oleh karena itu, rencana kegiatan harian $(\mathrm{RKH})$ juga harus dibuat setiap akan melakukan pembelajaran.

1) Perumusan Rencana Kegiatan Harian (RKH)

Menurut Fadillah (2012: 135) Rencana Kegiatan Harian yang baik adalah perencanaan pembelajaran yang dapat memuat dan merangkum seluruh materi yang akan disampaikan. Adapun langkahlangkah menyusun RKH menurut Fadillah (2012: 138) adalah sebagai berikut:

a) Mengisi kolom identitas

b) Menentukan alokasi waktu

c) Menentukan standar kompetensi dan kompetensi dasar, serta indikator yang akan digunakan yang terdapat pada silabus yang telah disusun

d) Merumuskan tujuan pembelajaran berdasarkan standar kompetensi dan kompetensi dasar, serta indikator yang telah ditentukan

e) Mengidentifikasi materi standar berdasarkan materi pokok/pembelajaran yang terdapat dalam silabus. Materi standar merupakan uraian materi pokok/pembelajaran

f) Menentukan metode pembelajaran yang akan digunakan

g) Merumuskan langkah-langkah pembelajaran yang terdiri dari kegiatan awal, inti, dan akhir

h) Menentukan sumber belajar

i) Menyusun kriteria penilaian, lembar pengesahan.

Berdasarkan langkah-langkah desain pembelajaran serta langkah-langkah merumuskan rencana kegiatan harian (RKH) di atas, disimpulkan mendesain 
pembelajaran adalah inti dari pembelajaran agar pembelajaran yang dilakukan mencapai tujuan yang diinginkan dan lebih jelas dan terukur.

2) Karakteristik desain pembelajaran Desain pembelajaran bukanlah suatu pekerjaan yang dilakukan secara tiba-tiba, melainakan suatu pekerjaan yang dilakukan secara terorganisir dan terperinci. Merujuk pada model-model desain pembelajaran yang memiliki karakteristik. Karakteristik desain pembelajaran menurut Reiser dan Dempey (dalam Yaumi, 2013: 65) adalah sebagai berikut:

a) Desain pembelajaran berpusat pada peserta didik

b) Desain pembelajaran berorientasi pada tujuan

c) Desain pembelajaran terfokus pada pengembangan atau kinerja peserta didik.

d) Desain pembelajaran bersifat empiris dan berulang-ulang.

Dengan demikian, mendesain pembelajaran bukanlah hal yang mudah, sehingga dibutuhkan guru yang benarbenar berkompenten dalam hal mendesai sehingga mampu mendesain pembelajaran yang berorientasi pada peserta didik, beroreintasi pada tujuan pembelajaran itu sendiri sehingga pembelajaran terfokus pada pengembangan atau kinerja peserta didik, dan yang paling penting desain pembelajaran harus bersifat empiris dan berulang.

Pembelajaran efektif di taman kanak kanak dalam prinsip pembelajaran aktif kreatif efektif dan menyenangkan (PAKEM) merupakan pembelajaran yang dapat meningkatkan efektivitas pembelajaran yang pada akhirnya dapat meningkatkan hasil belajar siswa. PAKEM adalah proses pembelajaran yang dirancang agar mengaktifkan anak, mengembangkan kreativitas sehingga efektif namun tetap menyenangkan (Fadillah \& dkk, 2014: 52). Keadaan aktif dan menyenangkan tidaklah cukup jika proses pembelajaran tidak efektif, yaitu tidak menghasilkan apa yang harus dikuasai peserta didik setelah proses pembelajaran berlangsung, sebab pembelajaran memiliki sejumlah tujuan yang harus dicapai. Jika pembelajaran hanya aktif dan menyenangkan tetapi tidak efektif, maka pembelajaran tersebut tak ada bedanya seperti bermain biasa.

Pada pelaksanaan pembelajaran seringkali terdapat masalah yang berkaitan dengan perilaku peserta didik, misalnya siswa yang ribut, bercakap-cakap ketika pelajaran, dan reaksi negatif terhadap siswa lain. Keragaman perilaku peserta didik yang negatif tersebut merupakan suatu permasalahan pendidik dalam menyelenggarakan proses pembelajaran. Realitanya, masih banyak guru yang belum mampu menciptakan pembelajaran secara efektif, dikarenakan hal tersebut dapat dipengaruhi oleh cara guru dalam menciptakan kondisi ruangan secara fisik maupun non fisik yang belum maksimal, sehingga mengakibatkan tujuan pembelajaran sedikit terhambat (Mulyadi, 2009: 8).

Undang-Undang Republik Indonesia Nomor 14 Tahun 2005 Bab 1 Pasal 1 ayat 1 dinyatakan bahwa guru merupakan pendidik profesional dengan tugas utama mendidik, mengajar, dan membimbing, mengarahkan, melatih, menilai dan mengevaluasi peserta didik pada anak usia dini jalur pendidikan formal, pendidikan dasar dan pendidikan menengah (Hidayat, 2017: 2). Seorang guru dituntut untuk dapat mengembangkan program pembelajaran secara optimal, sehingga terwujud proses pembelajaran yang efektif dan efisien. Tugas utama guru adalah menciptakan suasana di dalam kelas agar terjadi interaksi belajar mengajar yang dapat memotivasi siswa untuk belajar dengan baik dan sungguh-sungguh. Untuk menciptakan suasana yang dapat menumbuhkan semangat belajar, diperlukan pengorganisasian kelas yang memadai (Semiawan, 2011: 60).

Selain itu, guru juga harus memiliki seperangkat kompetensi tertentu. Kompetensi diartikan sebagai kedaulatan penguasaan pengetahuan, keterampilan, dan sikap yang ditampilkan melalui unjuk kerja (Kemdikbud, 2006). Salah satu kompetensi yang harus dimiliki guru adalah kompetensi profesional (UU Guru dan Dosen No. 14 Tahun 2005). Guru yang profesional akan tercermin dalam penampilan pelaksanaan pengabdian tugastugas yang ditandai dengan keahlian, baik dalam materi maupun metode. 
Salah satu ciri guru profesional adalah guru yang mampu mengelola kelasnya dengan baik, efektif dan tepat. Hal ini sesuai dengan apa yang dituliskan Sujiono (2013: 10), bahwa guru adalah orang yang memiliki kemampuan merancang program pembelajaran serta mampu menata dan mengelola kelas.

Pembelajaran akan berjalan efektif apabila guru memiliki kemampuan dalam mengelola kelas. Hal ini sejalan dengan penelitian Cerit (2015) bahwa pengelolaan kelas merupakan kunci dalam pembelajaran. Ruang kelas yang dikelola denganbaik terlihat dari manajemen kelas yang efektif. Yang ditandai dengan proses pembentukan, memelihara dan memulihkan lingkungan kelas dengan cara yang efektif untuk mengajar dan belajar.

Menurut Adezemo (2012) pengelolaan kelas merupakan kunci kegiatan pembelajaran di dalam lingkungan sekolah. Ruang kelas yang dikelola dengan baik akan dapat memberikan pengalaman yang menarik bagi anak dan bagi semua orang yang terlibat di dalamnya. Selain itu pengelolaan kelas juga dapat membuat anak lebih aktif dan membuat guru lebih mudah menangani permasalahan yang ada di kelas serta menghemat waktu yang dimiliki guru.

Daryanto (2015) berpendapat bahwa anak akan dapat menyerap ilmu pengetahuan dengan baik apabila ia belajar dalam suasana kelas yang kondusif. Salah satu cara untuk menciptakan suasana kelas yang kondusif adalah dengan cara mengelola ruang kelas sesuai dengan kebutuhan anak usia dini. Mengelola ruang kelas yang akan digunakan dalam pembelajaran anak usia dini tentunya harus mempertimbangkan kebutuhan anak seperti pemilihan bahan, manfaat atau kegunaan, ukuran, warna dan bentuk, serta rasa aman dan nyaman dari komponen yang ada dalam ruang kelas itu sendiri. Hal tersebut dipertegas oleh Maryana, et.al (2010) yang menyatakan bahwa kita perlu menyiapkan suatu lingkungan belajar yang benar agar mampu mengembangkan berbagai dimensi perkembangan anak secara optimal, serta diperkuat oleh Semiawan (2002) yang mengemukakan bahwa anak akan memberikan respon yang sesuai jika berada pada lingkungan belajar yang sistematis, terencana dan teratur.

\section{Pengelolaan Kelas di Taman Kanak- Kanak}

Menurut Djamarah (2005: 173) pengelolaan kelas adalah segala usaha yang dilakukan untuk mewujudkan terciptanya suasana belajar mengajar yang efektif dan menyenangkan. Atau dapat dikatakan suatu upaya mendayagunakan potensi kelas yang seoptimal mungkin untuk mendukung proses interaksi edukatif mencapai tujuan pembelajaran.

Usman (2004: 97) mengatakan pengelolaan kelas merupakan keterampilan guru untuk menciptakan dan memelihara kondisi belajar yang optimal dan membalikannya bila terjadi gangguan dalam proses belajar mengajar. Sedangkan Rusdinal \& Elizar (2011: 25), pengelolaan kelas adalah usaha sadar untuk mengatur kegiatan proses belajar mengajar secara sistematis. Usaha sadar itu mengarah pada penyiapan bahan belajar, penyiapan sarana dan alat peraga, pengaturan ruang belajar, perwujudan situasi/kondisi proses belajar mengajar dan pengaturan waktu sehingga pembelajaran berjalan dengan baik dan tercapainya tujuan pembelajaran.

Dari beberapa definisi tersebut di atas dapat disimpulkan bahwa pengelolaan kelas di taman kanak-kanak adalah keterampilan guru untuk menciptakan dan memelihara kondisi belajar yang optimal dan mengembalikannya manakala terjadi hal-hal yang dapat mengganggu suasana pembelajaran dengan memanfaatkan sumber daya yang ada yang meliputi pengelolaan peserta didik dan fasilitas yang mengarah pada penyiapan bahan belajar, penyiapan sarana dan alat peraga, pengaturan ruang belajar, perwujudan situasi/ kondisi proses belajar mengajar dan pengaturan waktu sehingga pembelajaran berjalan dengan baik dan tercapainya tujuan pembelajaran.

Pengelolaan kelas terbagi menjadi pengelolaan lingkungan fisik kelas dan pengelolaan lingkungan psikososial anak.

\section{a. Pengelolaan lingkungan fisik kelas}

Menurut Mariyana, dkk (2013: 34), Pengelolaan lingkungan belajar pada level TK atau prasekolah di antara pembagian paling popular adalah membagi lingkungan belajar ke dalam dua bagian besar yaitu:

1) Pengelolaan lingkungan dalam kelas (Indoor) 
Pengelolaan kelas juga meliputi penataan ruangan maupun pengorganisasian peserta didik sesuai kebutuhan dan program yang direncanakan akan membantu pencapaian standar kompetensi dan kompetensi dasar, serta tujuan pembelajaran secara optimal. Untuk itu hal-hal yang perlu diperhatikan dalam pengelolaan lingkungan fisik kelas menurut Mulyasa (2012: 151) adalah sebagai berikut:

a) Penataan sarana dan prasarana ruangan disesuaikan dengan kegiatan yang akan dilaksanakan

b) Pengelompokan meja dan kursi disesuaikan dengan kebutuhan anak sehingga mereka memiliki ruang gerak yang cukup luas. Susunan meja kursi dapat berubah-ubah pada waktu mengikuti kegiatan, anak tidak selalu duduk di kursi, tetapi juga dapat duduk di karpet/tikar.

c) Dinding dapat digunakan untuk menempel sarana yang dipergunakan sebagai sumber belajar dan hasil kegiatan anak, tetapi jangan terlalu banyak agar tidak mengganggu perhatian anak.

d) Peletakan dan penyimpanan alat bermain diatur sedemikian rupa sesuai dengan fungsinya sehingga dapat melatih anak untuk pembiasaan yang ingin dicapai seperti kemandirian, tanggung jawab, membuat keputusan, kebiasaan mengatur kembali peralatan dan sebagainya.

e) Alat bermain untuk kegiatan pengaman diatur dalam ruangan sehingga dapat berfungsi apabila diperlukan oleh peserta didik (Mulyasa, 2012: 151).

f) Kelas untuk anak TK perlu dirancang menyenangkan. Warna -warna terang dan riang sangat disukai anak. Akan tetapi jangan terlalu ramai warna karena dapat mengalihkan perhatian anak.

g) Cahaya matahari diusahakan dapat masuk dengan baik (Suyanto, 2005: 175).

2) Pengelolaan lingkungan di luar kelas (Outdoor)

Kegiatan di luar ruangan merupakan suatu bagian yang intergral dari program pendidikan anak usia dini. (Mariyana \& dkk, 2013: 36). Lingkungan belajar di luar kelas seyogyanya tidak hanya berperan sebagai tempat bermain melainkan juga sebagai tempat anak mengekspresikan lingkungannya.

Lingkungan ini merupakan tempat yang sangat menarik di mana anak-anak dapat tumbuh dan berkembang. Ketika anak-anak bermain di luar, mereka menunjukan ketertarikan serta rasa ingin tahu yang tinggi. Oleh karena itu lingkungan di luar kelas selalu penuh kejutan dan kaya akan perubahan.

Adapun aspek-aspek yang termasuk ruang lingkup pengelolaan lingkungan belajar outdoor (Mariyana \& dkk, 2013: 37) adalah:

a) Penataan lokasi kegiatan dengan berbagai sarananya

b) Penanganan pagar sekolah secara tepat

c) Pengelolaan tanah lapang

d) Perawatan dan penanganan pemukaan tanah

e) Pembuatan atap atau naungan

\section{b. Pengelolaan lingkungan psikososial anak}

Menurut Winataputra (2003), Iklim psikososial berkenaan dengan hubungan sosial-pribadi antara guru dan siswa dan antar siswa. Adanya hubungan yang harmonis antar komponen tersebut dapat menciptakan kelas yang sehat dan efektif bagi berlangsungnya proses pembelajaran.

Hal-hal yang perlu dilakukan guru dalam mengelola iklim psikososial anak yang efektif bagi keberlangsungan proses pembelajaran (Winataputra, 2003) adalah:

1) Disukai atau disenangi anak

2) Sabar, teguh, tegas, dan berwibawa

3) Akrab dengan siswa dalam satu konteks antara guru dan siswa

4) Adil dan bijaksana

5) Bersikap positif terhadap respon siswa

6) Mampu memberi motivasi dan nasihat.

Dengan demikian sikap profesional dan perilaku guru akan mewarnai bentuk-bentuk proses pembelajaran yang terjadi. Guru sebagai pengemban tugas langsung bertatap muka dengan siswa agar dapat membimbing aktivitas belajar siswa dan harus mampu menciptakan 
suasana belajar yang dapat mendorong siswa belajar dengan baik.

Sikap guru dalam proses pembelajaran cenderung memengaruhi perilaku guru dalam mengajar, perilaku guru dalam mengajar akan memengaruhi siswa dalam belajar. Siswa secara terus menerus mereaksi sikap, nilai dan kepribadian guru. Bila sikap guru terhadap pengajaran negatif, guru cenderung melakukan tugas mengajar menjadi sekadarnya dan tidak serius. Hal ini akan memengaruhi pula kepada suasana belajar siswa di kelas. siswa menjadi kehilangan motivasi untuk belajar. Akibatnya, hasil belajar siswa menjadi tidak memuaskan. Lain halnya guru akan cenderung melakukan tugas mengajar dengan baik sesuai dengan tugas dan tanggungjawab yang diembannya. Dampaknya sangat positif bagi situuasi belajar siswa sehingga dapat berdampak positif pula bagi hasil belajarnya.

Hubungan guru dan siswa merupakan hal yang tidak dapat dihindari dari kegiatan pengajaran. Keduanya berada pada satu situasi dan kondisi yang sama dengan tujuan mengubah (guru) dan berubah (siswa). Antara guru dan siswa harus terjadi interaksi yang harmonis dan serasi.

Dari uraian di atas, peneliti dapat menyimpulkan bahwa penciptaan suasana yang harmonis di dalam kelas menjadi syarat terciptanya lingkungan belajar yang kondusif. Guru dan siswa merasa menjadi bagian dari satu komunitas yang menyatu dalam rangka mencapai tujuan bersama, yaitu komunitas yang mendorong siswanya untuk mengenal guru yang terlibat dalam proses pembelajaran. Tujuan utamanya adalah agar guru dan siswa dapat lebih memahami satu sama lain. Pengembangan suasana sebagai bagian dari satu komuniats dan lingkungan psikososial yang positif dapat memotivasi siswa untuk belajar, terlibat dan membantu mereka untuk mengembangkan potensi secara optimal. Bahkan, siswa dapat pula memperoleh perkembangan lebih dari pembelajaran yang mereka lalui serta mendapatkan perkembangan yang baik.

Usaha guru dalam mengatur kelas berdasarkan pendekatan psikososial yaitu memahami konsep pendekatan psikososial tentang pembawaan,

1) Guru perlu mengenal latarbelakang anak dan kehidupan anak,
2) Memahami interaksi murid-murid dan murid guru,

3) Guru perlu memahami ilmu psikologi perkembangan dan

4) Sosial, guru perlu memahami diri sendiri.

\section{c. Prinsip- prinsip Pengelolaan Kelas di TK}

Menurut Bahri (dalam Erwin, 2018: 19) untuk memperkecil masalah dalam pengelolaan kelas, terdapat prinsip-prinsip pengelolaan kelas yang perlu diperhatikan oleh guru sebagai berikut:

1) Hangat dan antusias diperlukan dalam proses belajar mengajar. Guru yang hangat dan akrab dengan siswa selalu menunjukan antusias pada tugasnya pada aktivitasnya dapat berhasil dalam mengimplementasi pengelolaan kelas.

2) Tantangan, penggunaan kata-kata, tindakan, cara kerja dapat meningkatkan gairah siswa untuk belajar sehingga mengurangi kemungkinan munculnya tingkah laku yang menyimpang dapat menarik perhatian siswa, dan dapat mengendalikan gairah belajar siswa.

3) Bervariasi, penggunaan alat media, gaya mengajar guru, pola interaksi antara guru dan siswa dapat mengurangi munculnya gangguan, meningkatkan perhatian siswa. Apabila penggunaanya bervariasi merupakan kunci tercapainya pengelolaan kelas yang efektif dan menghindari kejenuhan.

4) Keluwesan, tingkah laku guru untuk mengubah strategi mengajarnya dapat mencegah kemungkinan munculnya ganguan siswa serta menciptakan iklim belajar mengajar yang efektif. Keluwesan pengajaran dapat mencegah munculnya gangguan seperti keributan siswa, tidak ada perhatian, tidak mengerjakan tugas.

5) Penekanan pada hal-hal yang positif, pada dasarnya dalam mengajar dan mendidik, guru harus menekankan pada hal-hal yang positif dan menghindari pemusatan perhatian siswa pada hal-hal yang negatif.

6) Penanaman displin diri, tujuan akhir pengelolaan kelas adalah siswa dapat mengembangkan disiplin diri sendiri, guru sebaiknya selalu mendorong siswa untuk melaksanakan disiplin dan guru hendaknya menjadi teladan mengenai pengendalian diri dan pelaksanaan tanggung jawab.

Berdasarkan uraian prinsip-prinsip di atas, dalam pengelolaan kelas seorang guru mesti 
tahu dan mempergunakan prinsip-prinsip pengelolaan kelas. Prinsip pengelolaan kelas itu sendiri merupakan pegangan atau acuan pokok dasar berfikir atau bertindak bagi seorang pendidik. Tujuannya adalah untuk menciptakan dan memlihara kondisi belajar yang optimal serta mengembalikannya bila terjadi gangguan dalam proses pembelajaran.

Uraian tersebut menjelaskan bahwa pengelolaan kelas merupakan hal yang sangat penting dalam pembelajaran anak usia dini. Melalui pengelolaan kelas anak dapat merasa lebih nyaman dan fokus pada saat berada di dalam ruangan maupun di luar ruangan. Anak akan lebih banyak berinteraksi dan aktif ketika belajar. Selain itu juga guru lebih banyak menghemat waktu serta dapat mengontrol kondisi yang ada di dalam kelas dan luar kelas secara lebih mudah. Namun pada kenyataannya, sebagian besar guru belum mampu melakukan pengelolaan kelas yang sesuai dengan kebutuhan dan karakteristik anak dengan yang seharusnya.

Berdasarkan hasil observasi awal pada tanggal 10 Maret 2019 di Taman Kanak-Kanak (TK) Kecamatan Rangkasbitung, dari beberapa TK yang diteliti, terdapat masalah yang berkaitan dengan proses pembelajaran terdapat siswa yang ribut di kelas, kurang memperhatikan guru ketika menjelaskan, bercanda dengan teman dan bercakap-cakap ketika guru menjelaskan, serta reaksi negatif terhadap siswa lain seperti saling dorong-mendorong, rebutan mainan dan saling pukul memukul. Guru yang bersikap kurang tegas, tidak menegur peserta didik yang mengganggu suasana kelas, penjelasan materi yang terlalu monoton dan kurangnya media yang digunakan pada saat menjelaskan materi pembelajaran. Realitanya masih banyak guru yang belum mampu menciptakan pembelajaran yang efektif dengan kondisi ruang kelas yang sempit sehingga peserta didik tidak leluasa mengikuti kegiatan di dalam kelas, merasa jenuh dikarenakan situasi pembelajaran yang monoton. Guru kurang maksimal mempersiapkan bahan belajar sehingga alat peraga yang digunakan menjadi kurang menarik bagi anak.

Dari beberapa TK yang diteliti realitanya masih banyak guru yang belum mampu menciptakan pembelajaran yang efektif. Ruang kelas yang sempit sehingga siswa tidak leluasa mengikuti kegiatan di dalam kelas, peserta didik merasa jenuh dan selalu meminta pulang. Hal ini disebabkan karena situasi pembelajaran tidak menyenangkan. Guru kurang mempersiapkan bahan belajar dengan maksimal, sehingga alat peraga yang digunakan menjadi kurang menarik bagi anak.

Dari permasalahan-permasalahan di atas, maka peneliti akan mengangkat topik dalam penelitian ini dengan judul "Pengaruh Kemampuan Guru dalam Mengelola Kelas Terhadap Pembelajaran Efektif di Taman Kanak-Kanak".

\section{METODE PENELITIAN}

Metode penelitian yang digunakan dalam penelitian ini adalah metode kuantitatif dengan menggunakan pendekatan ex post facto karena data yang diperoleh digunakan untuk meneliti peristiwa yang telah terjadi dan kemudian ditarik ke belakang untuk mengetahui faktorfaktor yang menimbulkan kejadian tersebut. Menurut Sugiyono (2017: 7), metode penelitian kuantitatif dapat diartikan sebagai metode penelitian yang berlandaskan filsafat positivisme, yang digunakan dalam populasi dan sampel tertentu, teknik samplingnya biasanya dilakukan secara random, sedangkan pengumpulan datanya menggunakan instrument. Untuk analisis datanya bersifat kuantitatif statistik dengan tujuan untuk menguji hipotesis yang telah ditetapkan.

Populasi pada penelitian ini sebanyak 61 dengan jumlah sampel sebanyak 38 responden. Teknik yang digunakan untuk menentukan sampel dalam penelitian ini adalah teknik Random Sampling. Teknik ini dilakukan untuk memilih satuan sampel dari populasi sedemikian rupa sehingga setiap satuan sampel dalam populasi mempunyai peluang yang sama besar untuk terpilih ke dalam sampel, dan peluang tersebut diketahui sebelum pemilihan dilakukan (Sedarmayanti \& Hidayat, 2011). Cara pengambilan sampel dalam teknik ini adalah dengan menggunakan rumus Slovin (Sedarmayanti \& Hidayat, 2011). 
Pengumpulan data dilakukan dengan menggunakan kuesioner (angket). Kuesioner (angket) adalah sejumlah pertanyaan tertulis yang digunakan untuk memperoleh informasi dari responden dalam arti laporan tentang pribadinya atau hal-hal yang diketahuinya (Arikunto, 2006: 128).

Uji validitas instrumen menggunakan rumus Korelasi Product Moment, sedangkan untuk uji reliabilitas instrumen menggunakan rumus Alpha Cronbach. Teknik analisis data yang digunakan adalah analisis regresi linear sederhana, dimana perhitungannya dibantu program SPSS. Untuk memenuhi persyaratan pemenuhan uji regresi maka perlu dilakukan uji persyaratan analisis yang meliputi uji normalitas dan uji linearitas. Uji persyaratan analisis dilakukan dengan maksud untuk memberikan gambaran tentang sejauh mana persyaratan telah dipenuhi sesuai dengan teknik analisis data yang telah direncanakan.

\section{HASIL DAN PEMBAHASAN}

\section{Deskripsi Tempat dan Karakteristik} Responden

Penelitian ini dilakukan di lembaga Taman Kanak-Kanak Kecamatan Rangkasbitung Kabupaten Lebak. Lembaga TK di Kecamatan Rangkasbitung berjumlah 20 lembaga dengan jumlah guru sebanyak 61 orang. Penelitian ini hanya menggunakan 8 lembaga TK untuk pengambilan data uji coba dan data sebenarnya. Penyebaran angket dilakukan selama 2 minggu (14 Hari), mulai dari tanggal 18-6 Agustus 2019. Dari 8 lembaga TK yang diteliti terdapat 1 (satu) Taman Kanak-Kanak (TK) memiliki Akreditasi A, 4 (empat) Taman Kanak-Kanak (TK) memiliki Akreditasi B, dan 3 (tiga) Taman Kanak-Kanak (TK) yang belum ter Akreditasi.

Hasil perhitungan karakteristik responden dapat dilihat pada tabel-tabel di bawah ini:
Tabel 1. Usia Responden

\begin{tabular}{|c|c|c|c|c|c|}
\hline & Frequency & Percent & $\begin{array}{l}\text { Valid } \\
\text { Percent }\end{array}$ & $\begin{array}{c}\text { Cumulative } \\
\text { Percent }\end{array}$ \\
\hline \multirow{11}{*}{ Valid } & $19-26$ & & & & \\
\hline & Tahun & 6 & 15,81 & 15,81 & 15,81 \\
\hline & $27-34$ & & & & \\
\hline & Tahun & 16 & 42,10 & 42,10 & 57,91 \\
\hline & $35-42$ & & & & \\
\hline & Tahun & 7 & 18,42 & 18,42 & 76,33 \\
\hline & $43-50$ & & & & \\
\hline & Tahun & 5 & 13,15 & 13,15 & 89,48 \\
\hline & $51-58$ & & & & \\
\hline & Tahun & 4 & 10,52 & 10,52 & 100,0 \\
\hline & Total & 38 & 100,0 & 100,0 & \\
\hline
\end{tabular}

Tabel 2. Lama Mengajar Guru

\begin{tabular}{cccccc}
\hline & & $\begin{array}{c}\text { Fre- } \\
\text { quency }\end{array}$ & $\begin{array}{c}\text { Valid } \\
\%\end{array}$ & Cum-ulative \% \\
\hline Valid & $\begin{array}{c}1-7 \\
\text { Bln }\end{array}$ & 5 & 13,15 & 13,15 & 13,15 \\
\cline { 2 - 5 } & $\begin{array}{c}1-6 \\
\text { Thn }\end{array}$ & 13 & 34,21 & 34,21 & 47,36 \\
\hline $\begin{array}{c}7-12 \\
\text { Thn }\end{array}$ & 10 & 26,31 & 26,31 & 73,67 \\
$\begin{array}{c}13-18 \\
\text { Thn }\end{array}$ & 6 & 15,81 & 15,81 & 89,84 \\
\hline $\begin{array}{c}19-24 \\
\text { Thn }\end{array}$ & 2 & 5,26 & 5,26 & 94,74 \\
\hline $\begin{array}{c}25-30 \\
\text { Thn }\end{array}$ & 2 & 5,26 & 5,26 & 100 \\
\hline Total & 38 & 100 & & \\
\hline
\end{tabular}

Tabel 3. Pendidikan Terakhir Guru

Deskripsi Data Hasil Penelitian

\begin{tabular}{ccccrr}
\hline & & Frequency & Percent & $\begin{array}{c}\text { Valid } \\
\text { Percent }\end{array}$ & Cumulative \\
\hline Valid & SMA & 11 & 28,95 & 28,95 & 28,95 \\
\hline Diploma & 3 & 7,90 & 7,90 & 36.85 \\
\hline S1 & 23 & 60,52 & 60,52 & 97,57 \\
\hline & 1 & 2,63 & 2,63 & 100 \\
\hline & 38 & 100 & 100 & \\
& & & & & \\
\hline
\end{tabular}


Deskrispi data hasil penelitian digunakan untuk melihat tingkat kategori kemampuan guru dalam mengelola kelas dan pembelajaran efektif di TK Kecamatan Rangkasbitung. Berikut adalah tabel rekapitulasi interval dan kategori kemampuan guru dalam mengelola kelas terhadap pembelajaran efektif di TK Kecamatan Rangkasbitung.

Tabel 4. Rekapitulasi Interval dan Kategori Kemampuan Guru dalam Mengelola Kelas

\begin{tabular}{llll}
\hline Interval & Frekuensi & $\begin{array}{l}\text { Presetase } \\
(\%)\end{array}$ & Kategori \\
\hline $38-47$ & 2 & 5.3 & $\begin{array}{l}\text { Sangat } \\
\text { Rendah }\end{array}$ \\
\hline $48-57$ & 3 & 7.9 & Rendah \\
\hline $58-67$ & 16 & 42 & Sedang \\
\hline $68-77$ & 14 & 37 & Tinggi \\
\hline $78-87$ & 3 & 7.9 & $\begin{array}{l}\text { Sangat } \\
\text { Tinggi }\end{array}$ \\
\hline Total & 38 & 100,0 & \\
\hline
\end{tabular}

Tabel 5. Rekapitulasi Interval dan Kategori Pembelajaran Efektif di TK Kecamatan Rangkasbitung.

\begin{tabular}{lllll}
\hline Interval & Frekuensi & $\begin{array}{c}\text { Persentase } \\
(\%)\end{array}$ & Kategori & Interval \\
\hline $33-42$ & 2 & 5.3 & $\begin{array}{c}\text { Sangat } \\
\text { Rendah }\end{array}$ & $33-42$ \\
& & & & \\
\hline $43-52$ & 3 & 7.9 & Rendah & $43-52$ \\
\hline $53-62$ & 15 & 24 & Sedang & $53-62$ \\
\hline $63-72$ & 9 & 39 & Tinggi & $63-72$ \\
\hline $73-82$ & 9 & 24 & $\begin{array}{l}\text { Sangat } \\
\text { Tinggi }\end{array}$ & $73-82$ \\
& & & & \\
\end{tabular}

Dari tabel tersebut diketahui bahwa Kemampuan guru dalam mengelola kelas dan pembelajaran efektif di TK Kecamatan Rangkasbitung berada pada kategori sedang.

Hasil analisis data yang dilakukan, menunjukkan beberapa hal, yaitu dari 38 responden yang merupakan guru Taman Kanak-
Kanak Kecamatan Rangkasbitung yang dibagi menjadi 5 kategori, yaitu kategori sangat rendah, rendah, sedang, tinggi, dan sangat tinggi, menujukkan tingkat variabel kemampuan guru dalam mengelola kelas (X) berada pada kategori sedang, dengan jumlah responden 16 responden pada jarak interval 5867. Sebanding dengan hasil tingkat kemampuan guru dalam mengelola kelas, hasil untuk tingkat variabel pembelajaran efektif di TK Kecamatan Rangkasbitung (Y) juga menunjukkan pada kategori sedang, dengan jumlah responden paling banyak, yaitu berjumlah 15 responden dengan jarak interval 53-56. Sedangnya tingkat kemampuan guru dalam mengelola kelas dan pembelajaran efektif di TK Kecamatan Rangkasbitung diperkuat dari hasil observasi dan wawancara bahwa kurangnya sarana dan prasarana yang memadai dan kurangnya pengetahuan guru tentang pengelolaan kelas. Tinggi rendahnya tingkat pendidikan, kurangnya pengetahuan dan kurangnya proses belajar juga akan memengaruhi kemampuan seseorang dalam mengelola kelas. Guru harus memiliki seperangkat kompetensi tertentu. Kompetensi diartikan sebagai kedaulatan penguasaan pengetahuan, keterampilan, dan sikap yang ditampilkan melalui unjuk kerja (Kementian Pendidikan dan kebudayaan, 2006).

Menurut Sujiono (2012: 10), guru adalah orang yang memiliki kemampuan merancang program pembelajaran serta mampu menata dan mengelola kelas. Pengelolaan kelas merupakan kunci kegiatan pembelajaran di dalam lingkungan sekolah. Ruang kelas yang dikelola dengan baik akan dapat memberikan pengalaman yang menarik bagi anak dan bagi semua orang yang terlibat di dalamnya. Selain itu pengelolaan kelas juga dapat membuat anak lebih aktif dan membuat guru lebih mudah menangani permasalahan yang ada di kelas serta menghemat waktu yang dimiliki guru (Adeyemo, 2012).

Menurut Bahri (dalam Erwin, 2018: 19) untuk memperkecil masalah dalam pengelolaan kelas, terdapat prinsip-prinsip pengelolaan kelas yang perlu diperhatikan oleh guru sebagai berikut: 1) hangat dan antusias diperlukan dalam proses belajar mengajar; 2) tantangan, penggunaan kata-kata, tindakan, cara kerja yang dapat meningkatkan gairah siswa untuk belajar; 3) bervariasi, menggunaan alat media, gaya mengajar guru, pola interaksi antara guru dan 4) 
keluwesan tingkah laku guru untuk mengubah strategi mengajarnya dapat mencegah kemungkinan munculnya ganguan siswa serta menciptakan iklim belajar mengajar yang efektif. 5) Penekanan pada hal-hal yang positif; 6) Penanaman displin diri.

\section{SIMPULAN DAN SARAN}

Terdapat pengaruh antara kemampuan guru dalam mengelola kelas terhadap pembelajaran efektif di Taman Kanak-Kanak". Di tunjukan dengan nilai persamaan regresi $\hat{\mathrm{Y}}=$ $54,256+0,135 X$. dan besaran R Square sebesar $1,6 \%$, sedangkan $98,4 \%$ pembelajaran efektif di TK Kecamatan Rangkasbitung dipengaruhi oleh variabel lain yang tidak dibahas dalam penelitian ini dipengaruhi oleh faktor-faktor lain selain kemampuan guru dalam mengelola kelas.

Berdasarkan hasil pengolahan dan analisis data rekapitulasi interval dan kategori "kemampuan guru dalam mengelola kelas berada pada kategori sedang dengan jumlah responden sebanyak 16 atau $42 \%$ dari keseluruhan responden pada interval 58-67. Dan pembelajaran efektif berada pada kategori sedang dengan jumlah responden sebanyak 15 atau $24 \%$ dari keseluruhan responden pada interval 53-62.

Saran yang dapat diberikan adalah: 1). Bagi guru: a. Hendaknya memiliki kemampuan yang baik tentang pengelolaan kelas dan menerapkannya dalam proses pembelajaran agar dapat menciptakan kondisi yang optimal; b. Guru hendaknya memiliki rencana pembelajaran sebelum kegiatan pembelajaran dilakukan dengan membuat rencana kegiatan harian (RKH) agar tujuan pembelajaran yang direncanakan tercapai sesuai dengan perkembangan anak. 2). Bagi sekolah hendaknya menyempurnakan fasilitas ruangan yang memadai, sarana prasarana lingkungan kelas indoor maupun outdoor, agar anak dapat belajar dengan nyaman dan fokus. 3). Bagi peneliti lain hendaknya dapat menjadikan penelitian ini sebagai referensi dan motivasi agar dapat menyusun penelitian lebih baik lagi terkait pengelolaan kelas.

\section{DAFTAR PUSTAKA}

Adeyemo. (2012). The relationship between effective clasroom management and students academis achievement. European Juornal of Education Studies: Nigeria. Volume 4 (3). $15 \mathrm{hlm}$. www.ozelacademy, diakses 20 Maret 2019

Aqib, Z. (2009). Belajar dan pembelajaran di taman kanak-kanak. Bandung: Yrama Widya.

Cerit, Y. (2015). Teacher's perceptions of classroom management orientations in turkish and latvia contexts: a comparative study. Journal of Educational and Instructional Studies in the World. Volume 5. No. 10

Daryanto. (2015). Pengelolaan kelas dan iklim sekolah. Yogyakarta: Gava Media.

Depdiknas. (2003). Undang-Undang RI No 20 tentang sistem pendidikan nasional. Jakarta.

—. (2005). Undang-Undang No 14 Tahun 2005 Tentang Guru dan Dosen. Jakarta. https://books.google.co.id/books?id=xL1li DUL9yIC\&pg=PA1\&dq=Depdiknas. $+(200$ 3).+UndangUndang $+\mathrm{RI}+\mathrm{No}+20+$ Tentang + Sistem + Pen didikan+Nasional+.+Jakarta.

Djamarah, S.B. (2005). Guru dan anak didik dalam interaksi edukatif. Jakarta: Rineka Cipta .

Erwin, W. (2018). Cerdas pengelolaan kelas. Yogyakarta: Diva Press.

Fadillah, dkk. (2014). Edutainment pendidikan anak usia dini. menciptakan pembelajaran menarik, kreatif, dan menyenangkan. Jakarta: Perdana Media.

Fadillah, M. (2012). Desain pembelajaran paud: tinjauan teoritik dan praktik. Jogjakarta: Ar-Ruzz Media

Gurupendidikan.com. (2019). Empat standar kompetensi guru. Di Akses pada 30 september 2019), dari https://www.gurupendidikan.co.id/kompete nsi-guru/

Harjali. (2019). Penataan lingkungan belajar strategi untuk guru dan sekolah. Seribu Bintang. Malang Jakarta Timur.

Isti Qoma, Dewi. (2016). Persepsi guru dalam mengelola ruang kelas PAUD. Skripsi. FKIP Universitas Lampung.

Mariyana R., Nugraha, A., Rachmawati, Y. (2010). Pengelolaan lingkungan belajar. Jakarta: Kencana Prenada Group 
- (2013). Pengelolaan lingkungan belajar belajar. Bandung: Kencana Pernada Group.

Miarso, Y. (2004). Menyemahi benih teknologi pendidikan. Jakarta: Prenoda Media.

Mulyadi. (2009). Classroom management. Malang: UIN-Malang Press

Mulyasa. (2013). Manajemen PAUD. Bandung: Remaja Rosdakarya .

Rusdinal., Elizar. (2005). Pengelolaan kelas di taman kanak-kanak. Jakarta: Departemen Pendidikan Nasional.

Sedarmayanti., Hidayat, S. (2011). Metodologi penelitian. Bandung: Mandar Maju .
Semiawan, C. (2008). Belajar dan pembelajaran prasekolah dan sekolah dasar. Jakarta: PT Index.

Stiyani, I.Y. (2014). Pengaruh kemampuan berfikir kritis dan kreativitas belajar terhadap prestasi belajar akuntansipada siswa kelas XI IPS SMA Negeri 1 Banyudono Tahun Pelajaran 2013/2014. Skripsi, Universitas Muhammadiyah Surakarta.

Sugiyono. (2017). Metode penelitian kuantitatif, kualitatif, $R \& B$. Bandung: Alfabeta. 